\title{
INTERAKSI DALAM PEMBELAJARAN IPA DI SEKOLAH DASAR WILAYAH PESISIR (STUDI FENEMENOLOGI DI SDN KERTASADA SUMENEP)
}

\author{
Habibi $^{1}$, Rini Yudiati ${ }^{2}$ \\ FKIP Universitas Wiraraja Sumenep ${ }^{1,2}$ \\ habibi_bk@yahoo.com ${ }^{1}$
}

\begin{abstract}
ABSTRAK
Pemahaman siswa akan materi pembelajaran sangat dipengaruhi oleh bagaimana pola interaksi yang dibangun oleh guru melalui metode pembelajaran yang digunakannya. Tujuan penelitian ini adalah untuk mendeskripsikan bagaimana pola interaksi dalam pembelajaran IPA di sekolah dasar di kawasan pesisir Sumenep, khususnya pada kasus ini adalah SDN Kertasada. Penelitian ini termasuk ke dalam jenis penelitian studi kasus, dengan teknik pengambilan data berupa observasi dan wawancara. Adapun teknik analisis data yang digunakan adalah teknik analisis interaktif Miles \& Huberman. Berdasarkan temuan penelitian diperoleh data bahwa pola interaksi pembelajaran IPA di SDN Kertasada meliputi empat katagori yaitu penjelasan menggunakan buku teks, tanya jawab semu, pemotivasian melalui penghargaan dan interaksi tertuntun dalam kerja kelompok.
\end{abstract}

Kata Kunci : interaksi, pesisir, analisis interaktif, pembelajaran IPA

\section{PENDAHULUAN}

Pembelajaran sebagai suatu sistem terdiri beberapa subsistem yang saling terkait dalam mewujudkan fungsinya sebagai suatu proses untuk meningkatkan kualitas diri siswa baik dalam domain kognitif, afektif ataupun psikomotor. Kondisi belajar anak di rumah merupakan salah satu subsistem tersebut. Subsistem yang lain adalah interaksi pembelajaran yang terjadi antara guru dan siswa di kelas. Dalam interaksi ini, guru dan siswa memiliki peran yang sama penting untuk menunjang keberhasilan pembelajaran.

Metode pembelajaran merupakan alat untuk menghasilkan interaksi yang positif antara guru dengan siswa ataupun diantara sesama siswa. Dalam interaksi yang bersifat komunikatif inilah sebenarnya kemungkinan besar pembelajaran dapat berhasil, melalui berbagai metode pengajaran. Seperti yang diungkapkan oleh Stolley (2005) bahwasannya dalam interaksi sosial manusia saling berbagi makna untuk menghasilkan pemahaman-pemahaman akan realitas.
Penjelasan Stolley memberikan suatu kejelasan mengenai bagaimana interaksi social terjadi, yaitu melalui proses berbicara, mendengar, mengamati, mengevaluasi dan juga membuat putusan-putusan tertentu berdasarkan cara-cara sebagaimana biasanya kita berinteraksi itu sendiri. Oleh karena itu perkembangan pemahaman dan sikap pada diri seseorang sangat dipengaruhi oleh interaksi sosialnya. Hubungan pengaruh tersebut terjadi dalam dua arah secara bolak-balik. Hal ini juga terjadi dalam interaksi pembelajaran di dalam kelas. Kualitas interaksi pembelajaran itu sangat menentukan bagaimana transfer makna antara guru dan siswa.

Salah satu teori dalam sosiologi mengenai proses interaksi sosial teori dari George Herbert Mead yaitu teori interaksi simbolik. Titik tolak pemikiran interaksi simbolik berasumsi bahwa realitas sosial sebagai proses dan bukan sesuatu yang bersifat statis. Dalam hal ini masyarakat dipandang sebagai sebuah interaksi simbolik bagi individu-individu yang ada didalamnya. Pada hakikatnya tiap 
manusia bukanlah "barang jadi" melainkan barang yang "akan jadi" karena itu teori interaksi simbolik membahas pula konsep mengenai "diri" (self) yang tumbuh berdasarkan suatu "negosiasi" makna dengan orang lain. Menurut George Herbert Mead, cara manusia mengartikan dunia dan dirinya sendiri berkaitan erat dengan masyarakatnya. Mead melihat pikiran (mind) dan dirinya (self) menjadi bagian dari perilaku manusia yaitu bagian interaksinya dengan orang lain. Mead menambahkan bahwa sebelum seseorang bertindak, ia membayangkan dirinya dalam posisi orang lain dengan harapanharapan orang lain dan mencoba memahami apa yang diharapkan orang itu (Mulyana, 2007).

Interaksi sosial, demikian pula yang terjadi dalam pembelajaran di kelas, berjalan melalui interaksi simbol-simbol yang dapat berupa kata-kata, gerak tubuh, obyek ataupun peristiwa-peristiwa tertentu (Stolley, 2005). Simbol-simbol ini merepresentasikan berbagai macam hal yang lain seperti pengetahuan, emosi, cerita atau ide-ide. Dengan demikian interaksi ini terjadi dalam setiap metode pembelajaran yang digunakan oleh guru.

Penelitian yang dilakukan Habibi, dkk (2011) mengenai permasalahan pembelajaran IPA di Kabupaten Sumenep memberikan temuan bahwa salah satu faktor yang menjadi masalah adalah pemilihan metode pembelajaran yang digunakan oleh para guru. Meskipun telah ada guru-guru yang menggunakan variasi metode dalam mengajar, namun sebagian besar masih berupa ceramah yang bersifat teacher centered. Hal ini menjadi kurang sesuai dengan prinsip IPA dalam KTSP (dalam Permendiknas no. 22 tahun 2006) yang menyatakan bahwa IPA bukan hanya penguasaan kumpulan pengetahuan yang berupa fakta-fakta, konsep-konsep, atau prinsip-prinsip saja tetapi juga merupakan suatu proses penemuan. Pendidikan IPA diharapkan dapat menjadi wahana bagi peserta didik untuk mempelajari diri sendiri dan alam sekitar, serta prospek pengembangan lebih lanjut dalam menerapkannya di dalam kehidupan sehari-hari. Proses pembelajarannya menekankan pada pemberian pengalaman langsung untuk mengembangkan kompetensi agar menjelajahi dan memahami alam sekitar secara ilmiah.

Tujuan penelitian ini adalah mendeskripsikan pola interaksi yang terjadi dalam pembelajaran IPA di sekolah dasar di kawasan pesisir Sumenep. Sekolah yang menjadi fokus dari penelitian ini adalah SDN Kertasada Sumenep.

\section{METODE}

Penelitian ini menggunakan pendekatan kualitatif fenomenologis, dimana tujuan utamanya adalah menggali makna terdalam dari suatu fenomena apa adanya. Adapun jenis penelitian yang digunakan adalah studi kasus. Dilaksanakan pada bulan Februari-Mei 2012. Adapun lokasi penelitian adalah di SDN Kertasada Sumenep. Secara spesifik lokasi penelitian yang akan banyak diobservasi adalah pada kelas saat pembelajaran IPA sedang berlangsung.

Untuk memperoleh data mengenai interaksi dalam proses pembelajaran IPA di SDN Kertasada Sumenep ini teknik pengumpulan data yang digunakan adalah Observasi dan Wawancara. Kedua teknik pengumpulan data ini diharapkan dapat saling melengkapi informasi yang dibutuhkan.

\section{Observasi}

Observasi dilakukan oleh peneliti untuk mendapatkan bagaimana secara riil proses pembelajaran IPA di SDN Karanganyar berlangsung, serta mengamati pola interaksi yang berlangsung serta hambatanhambatan dalam interaksi tersebut. Peneliti melakukan observasi secara langsung di dalam kelas saat terjadi pembelajaran, dan kadang-kadang 
juga melakukan observasi tak langsung dengan menempatkan alat perekam di kelas dengan tujuan untuk mengetahui bagaimana sebenarnya interaksi yang terjadi ketika peneliti tidak hadir di ruang kelas.

2. Wawancara

Wawancara digunakan oleh peneliti terutama untuk mengeksplorasi alasan-alasan di balik perilaku guru yang dimunculkan saat berinteraksi dengan siswa di kelas. Jenis wawancara yang dilakukan adalah wawancara semi terstruktur, yaitu wawancara dengan menyiapkan beberapa pokok pertanyaan yang masih dapat dikembangkan saat wawancara berlangsung untuk memperoleh data yang mendalam.

Teknis analisis data dalam penelitian ini menggunakan model analisis interaktif (Miles dan Huberman, 1992), seperti pada Gambar 1 berikut:

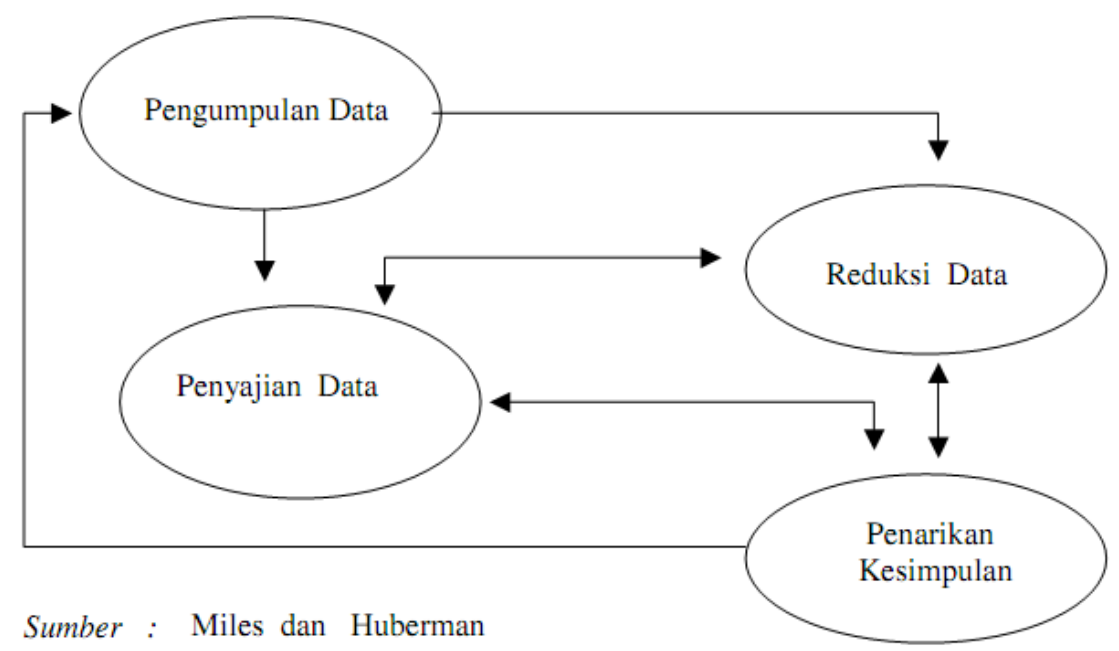

Gambar 1. Skema Analisis Interaktif (Miles \& Huberman, 1991)

\section{Reduksi Data}

Dari lokasi penelitian, data lapangan dituangkan dalam uraian laporan yang lengkap dan terinci. Data dan laporan lapangan kemudian direduksi, dirangkum, dan kemudian dipilah-pilah hal yang pokok, difokuskan untuk dipilih yang terpenting kemudian dicari tema atau polanya (melalui proses penyuntingan, pemberian kode dan pentabelan). Reduksi data dilakukan terus menerus selama proses penelitian berlangsung. Pada tahapan ini setelah data dipilah kemudian disederhanakan, data yang tidak diperlukan disortir agar memberi kemudahan dalam penampilan, penyajian, serta untuk menarik kesimpulan sementara.
2. Penyajian Data

Penyajian data (display data) dimasudkan agar lebih mempermudah bagi peneliti untuk dapat melihat gambaran secara keseluruhan atau bagian-bagian tertentu dari data penelitian. Hal ini merupakan pengorganisasian data kedalam suatu bentuk tertentu sehingga kelihatan jelas sosoknya lebih utuh. Data-data tersebut kemudian dipilah-pilah dan disisikan untuk disortir menurut kelompoknya dan disusun sesuai dengan katagori yang sejenis untuk ditampilkan agar selaras dengan permasalahan yang dihadapi, termasuk kesimpulan-kesimpulan sementara diperoleh pada waktu data direduksi. 
3. Penarikan Kesimpulan/Verifikasi Pada penelitian kualitatif, verifikasi data dilakukan secara terus-menerus sepanjang proses penelitian dilakukan. Sejak pertama memasuki lapangan dan selama proses pengumpulan data, peneliti berusaha untuk menganalisis dan mencari makna dari data yang dikumpulkan, yaitu mencari pola tema, hubungan persamaan, hipotetsis dan selanjutnya dituangkan dalam bentuk kesimpulan yang masih bersifat tentatif.

Ketiga komponen berinteraksi sampai didapat suatu kesimpulan yang benar. Dan ternyata kesimpulannya tidak memadai, maka perlu diadakan pengujian ulang, yaitu dengan cara mencari beberapa data lagi di lapangan, dicoba untuk diinterpretasikan dengan fokus yang lebih terarah. Dengan begitu, analisis data tersebut merupakan proses interaksi antara ke tiga komponan analisis dengan pengumpulan data, dan merupakan suatu proses siklus sampai dengan aktivitas penelitian selesai.

\section{HASIL DAN PEMBAHASAN}

Metode mengajar guru IPA di SDN Kertasada Sumenep secara umum terdiri atas dua jenis yaitu metode ceramah dan praktik. Berdasarkan observasi dan wawancara selama penelitian didapatkan perbedaan mendasar dari kedua metode tersebut. Tabel 1 berikut ini menunjukkan bagaimana perbedaan kelas ceramah dan kelas praktik.

Tabel 1 Tahap-tahap Pembelajaran IPA dalam Kelas Ceramah dan Kelas Praktik di SDN Kertasada Sumenep

\begin{tabular}{|c|c|c|}
\hline No & Pembelajaran IPA pada Kelas Ceramah & Pembelajaran IPA pada Kelas Praktik \\
\hline 1. & $\begin{array}{llll}\begin{array}{l}\text { Penyampaian } \\
\text { pembelajaran }\end{array} & \text { judul materi dan tujuan } \\
\end{array}$ & $\begin{array}{llll}\begin{array}{l}\text { Penyampaian judul materi dan tujuan } \\
\text { pembelajaran }\end{array} & & \\
\end{array}$ \\
\hline 2. & $\begin{array}{l}\text { Tanya jawab mengenai materi pada pelajaran } \\
\text { sebelumnya }\end{array}$ & $\begin{array}{l}\text { Tanya jawab mengenai materi pada pelajaran } \\
\text { sebelumnya }\end{array}$ \\
\hline 3. & Ceramah guru & $\begin{array}{l}\text { Pembagian kelompok dan penentuan ketua } \\
\text { kelompok oleh guru }\end{array}$ \\
\hline 4. & $\begin{array}{l}\text { Tanya jawab untuk mengecek pemahaman tanpa } \\
\text { melihat buku teks }\end{array}$ & Guru menerangkan prosedur kerja kolompok \\
\hline 5. & Latihan pendalaman dan hasilnya dikumpulkan & $\begin{array}{l}\text { Kerja kolompok. Guru berkeliling menuntun } \\
\text { kerja dan penyusunan laporan }\end{array}$ \\
\hline 6. & - & $\begin{array}{l}\text { Guru memberikan penghargaan pada kelompok } \\
\text { dengan kerjasama terbaik dan menasehati yang } \\
\text { masih buruk }\end{array}$ \\
\hline 7. & - & $\begin{array}{l}\text { Pembacaan hasil kerja kelompok oleh masing- } \\
\text { masing perwakilan kelompok }\end{array}$ \\
\hline 8. & - & Pembahasan hasil keseluruhan oleh guru \\
\hline 9. & - & Latihan soal pada LKS \\
\hline
\end{tabular}

Kedua metode pembelajaran IPA yang digunakan guru di SDN Kertasada tidak berlangsung proporsional. Metode ceramah lebih sering dilakukan. Sedangkan pola interaksi yang terbangun dalam pembelajaran IPA (melalui kedua metode yang digunakan) terbagi menjadi empat katagori utama yaitu Penjelasan berbasis buku teks, tanya jawab semu, pemotivasian melalui penghargaan dan interaksi tertuntun dalam kerja kelompok.

\section{Penjelasan berbasis Buku Teks}

Pembahasan materi oleh guru merupakan inti dari aktivitas belajar di kelas ceramah. Namun dalam kelas praktikpun guru juga menjelaskan materimateri tertentu. Pola interaksi dalam penjelasan guru tersebut ternyata 
memiliki kesamaan yaitu penjelasan yang berbasis informasi dalam buku teks. Dalam kelas ceramah guru menjelaskan berbagai konsep dan alat-alat IPA benarbenar berdasarkan buku teks. Alat-alat yang dijelaskan jarang sekali ditunjukkan secara nyata atau melalui gambar yang disiapkan guru melainkan melalui gambar yang telah ada di buku teks. Dalam kelas praktik penjelasan guru mengenai hasil kerja para siswa juga diberikan berdasarkan kalimat-kalimat yang ada dalam buku teks. Karakter penjelasan berbasis buku teks ini sangat berkaitan dengan pola interaksi yang pertama yaitu tanya jawab semu. Dalam tanya jawab, jawaban siswa tidaklah benar-benar dihasilkan dari proses berpikir melainkan langsung mencuplik kalimat-kalimat yang terdapat dalam buku teks. Kemungkinan besar siswa melakukan ini karena telah terbiasa mendapat penjelasan berbasis buku teks dari guru.

\section{Tanya Jawab Semu}

Tanya jawab merupakan teknik yang seringkali digunakan oleh guru baik dalam kelas ceramah maupun kelas praktik. Namun tanya jawab ini ternyata tidak memiliki pola interaksi sebagaimana tujuan dari sebuah tanya jawab yang sebenarnya dimana keaktifan berpikir siswa benar-benar dapat dimunculkan. Tanya jawab yang banyak terjadi dalam temuan penelitian ini adalah tanya jawab semu, artinya seperti telah terjadi tanya jawab antara guru dan siswa namun tidak demikian adanya. Guru hanya memotong kata terakhir dari penjelasannya untuk kemudian diikuti oleh siswa secara bersama-sama. Untuk lebih jelasnya kita perhatikan cuplikan data penelitian berikut.

Guru terus menjelaskan mengenai bagian-bagian mata. Suaranya lantang memenuhi ruang dengar di seluruh kelas. Anak-anak mendengarkan sambil mengikuti kata-kata kunci yang ekornya sengaja dipotong oleh guru untuk dilengkapi oleh siswa secara bersamaan seperti:

$\begin{array}{ll}\text { Guru } & \begin{array}{l}\text { bagian mata yang } \\ \text { melindungi bagian dalam } \\ \text { yang berupa selaput bening } \\ \text { disebut dengan korne... }\end{array} \\ \text { Siswa } & \begin{array}{l}\text { aaaa... } \\ \text { Guru }\end{array} \\ & \begin{array}{l}\text { sedangkan bagian paling } \\ \text { dalam yang menjadi tempat } \\ \text { terbentuknya bayangan }\end{array} \\ & \text { adalah ree... } \\ \text { siswa } & \text { tinaaaa... } \\ \text { guru } & \text { kemudian bayangan itu } \\ & \begin{array}{l}\text { diproses oleh saraf di otak. } \\ \text { Saraf itulah yang menterje... }\end{array} \\ \text { siswa } & \text { : jemahkaaan... } \\ \text { (Data Observasi kelas, } 7 \text { Maret 2012). }\end{array}$

\section{Pemotivasian melalui Penghargaan}

Motivasi merupakan unsur yang sangat pendting bagi kesuksesan sebuah proses pembelajaran. Guru-guru berpengalaman akan selalu memperhatikan bagaimana cara memotivasi siswa untuk belajar. Dalam penelitian ini didapatkan temuan bahwa pola interaksi guru dan siswa yang khas juga terjadi ketika guru melakukan pemotivasian terhadap siswa baik dalam kelas ceramah maupun kelas praktik. Pemotivasian yang dilakukan guru adalah pemotivasian berbasis penghargaan secara lisan terhadap perilaku-perilaku yang diharapkan dapat terus dilakukan oleh setiap siswa. Setelah guru memberikan penghargaan lisan maka siswa-siswa yang lain akan bertepuk tangan.

\section{Interaksi Tertuntun dalam Kerja Kelompok \\ Pola interaksi terakhir yang} menjadi pembahasan dalam penelitian ini adalah pola interaksi yang terjadi dalam kerja kelompok. Pola ini umumnya terjadi dalam kelas praktik. Kerjasama diantara anggota-anggota kelompok dalam menjalankan tugas yang diberikan oleh guru menuntut pembagian tugas dan pemahaman para siswa yang baik akan tugas itu sendiri. Namun tampaknya pemahaman prosedur yang dimiliki siswa 
masih sulit sekali muncul sehingga dalam kerja kelompok guru harus sering berteriak mengulang-ngulang langkah kerja yang terdapat dalam Lembar Kegiatan Siswa. Seringkali guru juga harus turun tangan untuk menunjukkan prosedur-prosedur tertentu yang sulit untuk dilakukan oleh siswa. Guru juga sering melakukan peneguran pada siswasiswa yang tidak aktif dalam kerja kelompok. Berikut salah satu contoh bagaimana pola interaksi dalam kelompok berlangsung.

Anak-anak melakukan aktivitas dengan senang hati, beberapa kelompok malah sambil bergurau. Mengaduk campuran tanah dan air sambil bersenandung, "kopi-kopi jahee..." guru berkeliling mengatur aktivitas para siswa baik dalam mengamati adukan tanah ataupun menuliskan laporan hasil pengamatan. Suasana sangat ramai, baik bergurau sesama teman ataupun bertanya kepada guru, "bu, bu.. ini digambar ya..?" berteriak salah seorang anak. Begitulah, siswa yang hendak bertanya akan berteriak memanggil gurunya sehingga menambah ramai suasana kelas. Namun mereka melakukannya dengan riang (Data Observasi Kelas, 5 Maret 2012).

\section{Interaksionisme}

simbolik mengandung inti dasar pemikiran umum tentang komunikasi dan masyarakat. Jerome Manis dan Bernard Meltzer (Mulyana, 2001) memisahkan tujuh hal mendasar yang bersifat teoritis dan metodologis dari interaksionisme simbolik, yaitu:

1. Orang-orang dapat mengerti berbagai hal dengan belajar dari pengalaman. Persepsi seseorang selalu diterjemahkan dalam simbol-simbol.

2. Berbagai arti dipelajari melalui interaksi di antara orang-orang. Arti muncul dari adanya pertukaran simbol-simbol dalam kelompokkelompok sosial.
3. Seluruh struktur dan institusi social diciptakan dari adanya interaksi di antara orang-orang.

4. Tingkah laku seseorang tidaklah mutlak ditentukan oleh kejadiankejadian pada masa lampau saja, tetapi juga dilakukan secara sengaja.

5. Pikiran terdiri dari percakapan internal, yang merefleksikan interaksi yang telah terjadi antara seseorang dengan orang lain.

6. Tingkah laku terbentuk atau tercipta di dalam kelompok sosial selama proses interaksi.

7. Kita tidak dapat memahami pengalaman seorang individu dengan mengamati tingkah lakunya belaka. Pengalaman dan pengertian seseorang akan berbagai hal harus diketahui pula secara pasti.

Interaksi sosial, demikian pula yang terjadi dalam pembelajaran di kelas, berjalan melalui interaksi simbol-simbol yang dapat berupa kata-kata, gerak tubuh, obyek ataupun peristiwa-peristiwa tertentu (Stolley, 2005). Simbol-simbol ini merepresentasikan berbagai macam hal yang lain seperti pengetahuan, emosi, cerita atau ide-ide. Dengan demikian interaksi ini terjadi dalam setiap metode pembelajaran yang digunakan oleh guru.

Berbagai pola sikap yang ditampilkan oleh guru dan siswa dengan demikian merupakan hasil dari proses interaktif yang menciptakan pengetahuan, keyakinan dan persepsi dalam diri mereka. Siswa memunculkan sikap yang cenderung patuh dan mengikuti perintahperintah guru secara pasif kemungkinan dikarenakan perilaku guru terhadap mereka sejak lama. Sedangkan guru memiliki sikap terlalu menuntun dan cenderung berorientasi buku teks kemungkinan karena kebiasaan (dan juga merupakan warisan dari guru-guru sebelumnya) serta pola belajar yang kurang aktif (seperti halnya murid-murid mereka sekarang) untuk dapat merubah dan mengembangkan kualitas kepengajaran mereka menjadi lebih baik. 
Walau demikian pola-pola pemberian penghargaan bagi perilaku yang diharapkan dan nasehat bagi perilaku yang tidak diharapkan yang dilakukan siswa terus-menerus merupakan kelebihan yang perlu untuk dipertahankan bahkan dikembangkan dengan metode yang lebih bervariasi.

\section{KESIMPULAN DAN SARAN}

\section{Kesimpulan}

Pola interaksi dalam pembelajaran IPA di SDN Kertasada yang sering terjadi baik dalam kelas ceramah maupun kelas praktik adalah: (1) tanya jawab semu, (2) penjelasan berbasis buku teks, (3) pemotivasian melalui penghargaan, dan (4) interaksi tertuntun dalam kerja kelompok.

\section{Saran}

Pola interaksi dalam pembelajaran IPA di masyarakat pesisir (dalam kasus ini di SDN Kertasada) dapat menjadi landasan bagi pengembangan model pembelajaran yang sesuai untuk diterapkan di sekolah, untuk itu dibutuhkan suatu informasi pelengkap mengenai bagaimana perbedaan kondisional yang terjadi dengan sekolahsekolah yang lain.

\section{DAFTAR PUSTAKA}

Habibi, Anekawati, Anik \& Azizah, L.F. 2011.

Permasalahan

Pembelajaran IPA SMP/MTs di Kabupaten Sumenep 2010-2011. Sumenep: PRODI PENDIDIKAN IPA UNIJA

Miles, M.B. \& Huberman, A.M. 1992. Analisis Data Kualitatif. Penerjemah Tjetjep Rohindi Rohidi. Jakarta : Universitas Indonesia Press

Mulyana, Deddy dan Solatun, (ed.), 2007. Metode Penelitian Komunikasi; Contoh-contoh Penelitian Kualitatif dengan Pendekatan Praktis. Remaja Rosdakarya, Bandung.
Mulyana, Deddy, 2001. Metodologi Penelitian Kualitatif; Paradigma Baru Ilmu Komunikasi dan Ilmu Sosial Lainnya. Remaja Rosdakarya, Bandung.

Stolley, K.S. 2005. The Basics of Sociology. London: Greenwood Press 
Jurnal Lentera Sains - Prodi Pendidikan IPA

16 Jurnal Lensa, Volume 4 Jilid 2 November 2014 